\title{
FINANCIAL REPORTING - KEY TO SUCCESS IN THE BUDGET AND PUBLIC SECTOR IN THE REPUBLIC OF MACEDONIA
}

\author{
Igor Zdravkoski*, Miroslav Andonovski, Borka Sokoloski \\ Faculty of Economics - Prilep, University “St.Clement Ohridski” - Bitola, Prilepski braniteli, Prilep, Republic of Macedonia
}

\begin{abstract}
:
Accounting represents a "bridge" that connects the past and future activities relevant for the overall economic growth of any country. In fact, accounting information creates preconditions for continuous, systematic and comprehensive performance monitoring and business circumstances, but it also represents the basis for making efficient business and non-business decisions. In the broadest sense of the word, accounting information systems are perceived as those that illuminate the path of the future activities. Accounting information system is a computerized tool that collects, records, stores, processes accounting and financial data and provides support to management in the decision-making process. Actually, it should aim to enhance performances of an enterprise and produce economic benefits. The economic growth of a country creates changes that affect even the smallest segments of business operations. Accounting information systems reflect such changes- all events and transactions in either private or public companies are processed through these systems. Budget accounting, as part of the accounting information system, collects evidence of the entity's budget. Besides financial accounting that records events in both public and private sector, there are also budgetary accounting reports that are applied to the state, public and non-profit companies and organizations.
\end{abstract}

\section{Key words:}

accounting information system, budget accounting,

public sector.

\section{INTRODUCTION - FINANCIAL REPORTING IN BUDGET}

One of the main objectives of any country is to achieve growth and record favourable business outcomes. Of course, this requires developing an appropriate strategy that should be based on valid and accurate information.

Upon successfully implementing the national strategy, we should propose that budget that would meet the needs and objectives set by the Government. This means that the success of the strategy depends on recognizing and analyzing certain accounting and financial information on the budget of the Republic of Maceodnia, the budget of local government and funds, beneficiaries and spending of budget funds and funds provided by other legal entities.

In such context, accounting information system provides relevant information on the accounting systems, business books, accounting documents and data processing, recognition of revenues and expenses, balance positions estimation, revaluation, financial reports, etc.

The vital issue that should be addressed refers to the necessity of keeping records on the budget. The reason for that is that the budget of the Republic of Macedonia is an act containing annual budget plans and other revenues, authorized and approved funds from the budget. The reliability of the budget will depend on the overall quality of all activities performed.

It used to be necessary once to determine the procedure, adopt, implement and prepare the budget and municipal budgets, as well as perform reporting and execution.

Using the budget principles and information obtained from the accounting information system (AIS), the budget and the budgets of municipalities are created and adopted for a period of one fiscal year (12 months) starting from January 1 st and ending on December 31 st.

\section{BUDGET USERS - SUCCESSFUL FINANCIAL MANAGERS}

The first budget users are the legislative, executive and judicial powers, also users of the budge funds of municipalities and users based on the law of entrusted public authorizations. Individual users of the budget of the Republic of Macedonia are the institutions operating in the field of education ,science, culture, judiciary and prosecuting bodies, child welfare etc. 
Besides these users and individual users of budget funds, it is necessary to mention the Health Insurance Fund of Macedonia, the Pension and Disability Insurance Fund of Macedonia, the Road Fund, the Employment Agency of the Republic of Macedonia and some other agencies and institutions.

It is also worth noting that the local governmental units are also using the central budget funds.

The paper deals with the meaning and significance of AIS and financial reporting, as various transactions occur in its records as a final outcome of their work, showing the overall situation of the state i.e. budget and public companies. In this, we perceive the principles of transparency, inclusiveness, equilibrium, economy, efficiency, effectiveness, and achieve the principle of safe financial management. This means that the appropriations for budget users, managers and directors should be carried out for the purposes relating to the financing of the current, capital and other expenditures of budget users and their spending units to carry out activities presented by programs. It is forbidden to make commitments that are due in the current year or to incur expenditures above appropriations.

In fact, the unused assets together with the budget will not be valid on December 31st of the current fiscal year.

In this way, through financial reporting analysis of the central budget or the budgets of municipalities planned for unforeseen circumstances as permanent and current budget reserve.

These appropriations are used for elimination of consequences of natural disasters, epidemics, environmental disasters, and they can not be converted to redistribution throughout the year, but can only increase.

\section{FINANCIAL STATEMENTS - LEGAL OBLIGATION OF BUDGET USERS IN MACEDONIA}

Financial reporting is based on the key data and financial ratios contained in the balance sheets, which means that is is necessary that every budget user prepares financial statements.

However, preparation of financial statements as per the accounting information system is a legal obligation, where budget users are obliged to draw up a set of accounts, including:

- Balance sheet, the report shows the state of assets, liabilities and sources of funds for a specific period,

- Income statement, a report disclosing revenues and other expenses and incurred costs,

- Consolidate balance sheet, a report that contains a thorough review of revenues and expenditures of the individual users who are part of budget holder, and are not prepared in accounting Budget of Republic of Macedonia and accountancy of the budgets of local government units.

According to the regulations, obligatory actions in preparation of the annual reports include:

1. State budget,

2. The budgets of local government units,

3. The budgets of funds,

4. National Employment Office together with its regional offices,

5. Republican Road Fund along with its units, and
Through these basic financial statements prepared for the period of one fiscal year, anyone interested can see accurate, truthful and complete overview of revenues and other inflows, expenditures and other losses, and the amount of assets, liabilities and sources of funds. All these reports with its particularities constitute annual accounts and are stored permanently in their original form. The budgets of the funds shall prepare consolidated annual accounts.

After all, each individual - user (Fund) shall prepare the final account and submit it to the user it belongs to, no later than March 1st of the current year for the previous fiscal year.

Thus, users of the budgets and funds prepare consolidated annual reports and submit them to the Ministry of Finance no later than March 31st of the current year for the previous fiscal year. On the basis of the annual reports of the beneficiaries and the funds, the Ministry shall prepare the final report in accordance with the classification of revenue and classification of expenditure adopted by the Ministry of Finance.

This report discloses planned and realized revenues and expenditures of the State Budget no later than May 31st of the current year and submitted to the Government of Macedonia.

The final report includes the following:

- Review of collected revenues and realized expenditures of all budget reports from the Macedonian budget, compared to estimates of budget revenues and costs, and an explanation of major deviations,

- A detailed overview of the spending from the budget reserve, and

- Guarantees for loans taken in the fiscal year.

Also, the final accounts of the budgets of local government units are prepared and attached to the annual budget report. These reports are adopted by the municipal councils by March 15th and submitted to the Ministry of Finance no later than March 31st. The government submits it to the Parliament for adoption of the final report for the execution of the projected revenues and expenditures of the State Budget after its establishment by the Government, along with the annual accounts of the budgets of local governments and funds no later than June 30th of the current year for the previous fiscal year.

Budgets and budget users are obliged to submit the final reports to:

1. Register of annual accounts with the Central Registry of the Republic of Macedonia,

2. The State Audit Office, and by the end of the next February or within 60 days from the date of the status change.

After all, according to the budget law, every consumer and user of funds from the State Budget, off-budget funds and budgets of local government units are obliged and responsible for the accounting in accordance with legal regulations.

Namely, the Act regulated the process of maintaining of the accounting records, business books, documentation, data processing, recognition of revenues and expenditures, the assessment of balance sheet items, revaluation, financial reports, submission of financial statements and other issues related to the accounting of the Budget of Macedonia, the budgets of local government budgets and funds, beneficiar- 


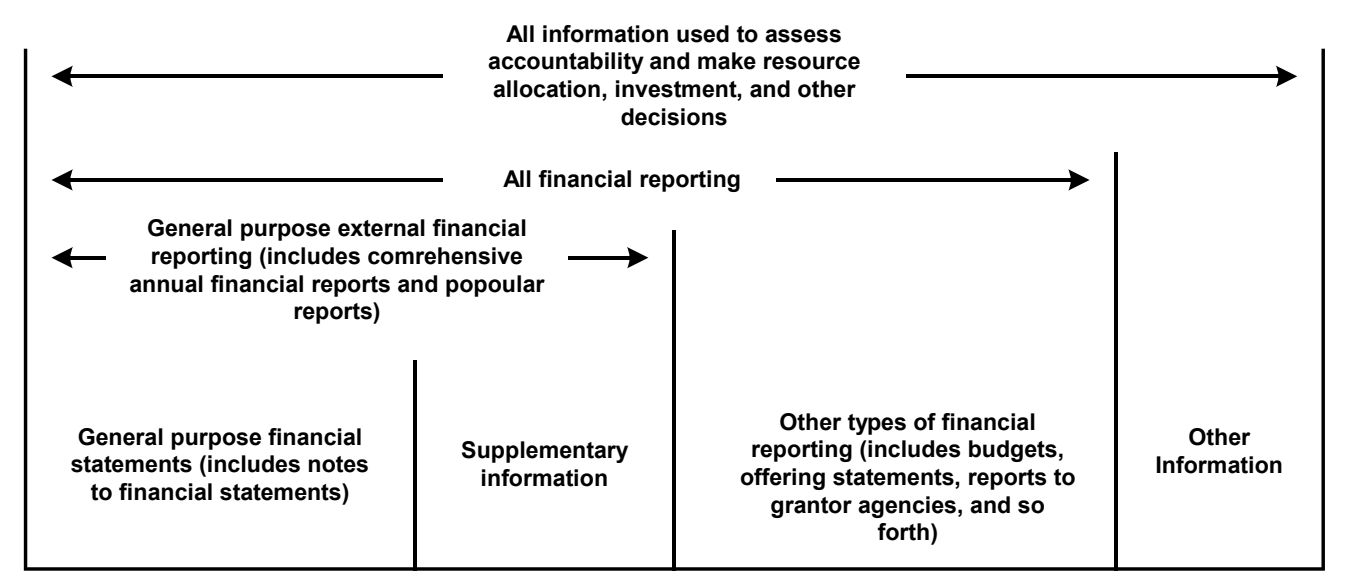

Illustration 1-2. Information Used by Financial Statement Users

Source: GASB (Government Accounting Standards Board), Codification, Appendix B, Figure 1.

ies and spending of budget funds from the budget and other entities for which the funds for basic activity mainly provide budgets.

Budgets and budget users are obliged to keep accounting records in the system of double accounting, to prepare and submit financial statements in accordance with the Low on accounting of budgets and budget users, accepted accounting principles, accepted accounting practice and standards, in order to accurately, truthfully, reliably, comprehensively, timely express balance sheet items, state budget funds and other assets, liabilities, sources of funds, revenues and other inflows and expenses and other losses and results of business operations.

The schedule of reports is performed according to the chart of accounts for the budget and budget users. Business records that are required to be kept are: journals, general ledgers, cash books, a book of capital assets and subsidiary ledgers. The following is encountered as subsidiary ledges: books of incoming invoices, books of outgoing invoices, books of purchases, inventories and book of receivables and payables. These books are public documents. Business books at the end of the fiscal year are locked and signed. Regardless of the manner of maintaining and keeping the business books, they should be available, protected and their accurate presentation should be guaranteed. It should provide the authentic, true and complete accounting documents. It should also provide regular internal control.

Such controls should confirm whether the financial changes, meaning transactions are in accordance with legal regulations for adequate accounting records and whether the financial statements provide complete, truthful and reliable information on the results of the financial changes and financial transactions.

Budgets and budget users and individual users are obliged to keep separate accounting records for the funds realized in the budget on other grounds, such as:

- Revenues from the authorities,

- Revenues from additional activities of budget users,

- Revenues from donations,

- Proceeds from loans, and

- Other revenues.

\section{BUDGETARY CONTROL - FACTOR FOR QUALITY MANAGEMENT IN FINANCE}

The questions that remain unsolved is related to the budgetary control and how it is distributed in accordance with the Law and how it is voted in the Parliament.

The primary task of budgetary control is to identify compliance with the regulations when executing the budget and whether it is done as approved by Parliament of Republic of Macedonia. Budgetary control is precisely oversight bodies that carry out the budget.

In this context, it means:

- Monitor the full and timely collection of revenues;

- Monitor timely payment of expenses in accordance with the procedures of the commitments and execution of payments;

- Monitor compliance of the budget as a whole or for individual budget lines with the procedures adopted by the head of the entity and / or the Minister of Finance;

- Monitor the effectiveness of budgetary control carried out by the managers in the management of their share of the budget, which should confirm whether the budgets are exceeded or not, that the assignments between the budget items are made pursuant to the objectives and / or purpose and budget items carried out in the year for the intended year;

- Monitor the budgetary and financial reporting;

- Advise and encourage managers to implement effective, efficient, orderly, verifiable and complete financial management and control; and

- Implement control audit trail established by managers in the organization.

\section{CONCLUSION}

Based on the above-mentioned and having in mind the importance of financial reporting in the state and public sector, it is necessary for budgetary units and budget users to certify the information they receive from the accounting information system as a foundation in their operations. 
This also represents creation of a database from which managers and other budget users gather information, analyses financial data, create development plans and intended use of funds and assets.

Namely, the financial management of budgetary entities is obliged to prepare and interpret financial statements, as they would serve all stakeholders and confirm transparency of information in the overall system. Such strategic decisions aim to improve the overall actions of the state and public sector, allow for greater access and insight into financial management.

Contemporary business conditions cannot be ignored nor the comments and needs of citizens. The Republic of Macedonia, as other democratic societies, strives towards achieving efficient and effective financial management, greater economic growth and development and optimize business results.

Therefore, in order to have well-prepared, adopted and implemented budget, it is necessary to have a quality information system and trained staff that could respond properly to the needs of the most demanding users of financial statements.

Since accounting is considered a tool necessary for proper understanding of finance, it is necessary to conform the quality of financial reporting, as a key to success and goal achievement.

In this respect, we would like to emphasize the efforts made by the Republic of Macedonia, including the implementation and application of international accounting standards in the public sector, compliance with the rules and procedures of state accounting and accounting of non-profitable organizations, and that they are adopted in accordance with the Law on budget accounting with the aim to ensure complete, high-quality and timely financial reporting.

\section{REFERENCES}

Block, S.B., \& Hirt, G.A. (2008). Foundations of financial management. Boston: McGraw Hill/Irwin.

Hermanson, E.M. (1998). Accounting: a business perspective. Boston: McGraw Hill.

Horngren, S., \& Elliot, J.A. (2006). Introduction to Financial Accounting. Upper Saddle River, NJ: Prentice Hall.

Needles, B.E., Powers, M. (1999). Principles of Accounting. Boston: Houghton Mifflin.

Perry, J. T., \& Schneider, G.P. (1995). Building accounting systems: Using Access 97. Cincinnati: South-Western College.

Rama Gopal, Ca.C. (2009). Accounting for Managers. New Delhi: New Age International.

Robinson, T.R., Henry, E., Pirie, W.L., \& Broihahn, M.A. (2015). International Financial Statements Analysis. Hoboken, New Jersey: John Wiley and Sons.

Wild, J. J., Shaw, K.W., \& Chiappetta, B. (2011). Fundamental accounting principles. New York: McGraw-Hill Irwin.

Wilson, E.R., Hay, L.E., \& Kattellus, S.C. (1999). Accounting for governmental and nonprofit entities. Boston: Irwin/ McGraw-Hill.

Zdravkoski, I. (2007). Standardization and Application of Financial Statements. EFP, RM.

\section{FINANSIJSKO IZVEŠTAVANJE - KLJUČ USPEHA U BUDŽETSKOM SISTEMU I JAVNOM SEKTORU U REPUBLICI MAKEDONIJI}

\footnotetext{
Apstrakt:

Računovodstvo predstavlja sponu između prethodnih i budućih aktivnosti koje su od značaja za sveukupni ekonomski razvoj zemlje. Naime, računovodstvene informacije predstavljaju preduslov za kontinuirano, sistematsko i sveobuhvatno praćenje performansi i poslovnih okolnosti, ali i osnovu za uspešno donošenje poslovnih odluka. U najširem smislu te reči, informacioni računovodstveni sistemi predstavljaju aktivnosti koje stvaraju osnovu za buduće aktivnosti. Informacioni računovodstveni sistem predstavlja kompjuterizovan sistem koji prikuplja, evidentira, pohranjuje i obrađuje računovodstvene i finansijske podatke i pruža neophodne informacije koje su od značaja za rukovodstvo u procesu donošenja odluka. Zapravo, nijihova uloga jeste i da utiču na poboljšanje performansi preduzeća i ostvarenje ekonomske dobiti. Ekonomski razvoj zemlje dovodi do promena koje utiču i na najmanji segment poslovanja. Informacioni računovodstveni sistemi ukazuju na takve promene - svi događaji i transakcije u okviru državnih i privatnih preduzeća obuhvaćeni su ovim sistemima. Budžetsko računovodstvo, kao deo informacionog računovodstvenog sistema, prikuplja dokaze o budžetu privrednog društva. Pored finansijskog računovodstva koje prati događaje u javnom i privatnom sektoru, postoje i budžetski računovodstveni izveštaji koji se primenjuju na državna, javna i neprofitabilna preduzeća i organizacije.
}

\section{Ključne reči:}

računovodstveni informacioni sistem, budžetsko računovodstvo, javni sektor. 